\title{
POST-GLACIAL MOLLUSCA FROM THE MARLS OF CENTRAL ILLINOIS
}

\author{
FRANK COLLINS BAKER \\ Curator, Museum of Natural History, University of Illinois
}

The study of the biota contained in marl beds, and in other deposits lying upon the till of the late Wisconsin ice sheet, has added greatly to our knowledge of the post-glacial distribution of many mollusks and other animals, and has often provided data bearing on the changes of climate which have occurred during the interval between the retreat of the Wisconsin ice and the present time. The material that forms the basis for the present contribution adds to our knowledge concerning the post-glacial distribution of a few lacustrine and fluviatile forms of mollusks.

My thanks are due Dr. T. E. Savage, of the University of Illinois, for the opportunity of examining the material as well as for stratigraphic data bearing upon the deposit containing the collections; Dr. V. Sterki and Dr. Bryant Walker for the examination of critical material; and Professor Frank Smith for assistance in collecting material from the vicinity of Mahomet.

Marl deposits are extensively distributed in Michigan, Wisconsin, Maine, New Jersey, and other localities, being better known in the states named than elsewhere. Indiana, Ohio, and Illinois also contain marl beds of greater or less size, but these have not been as exhaustively studied for their biota. Marl deposits have rarely been reported from Illinois, a condition due to lack of observation rather than to absence from the territory.

The study of these marl deposits is of great interest and some value, a comparison of the marl fauna with the recent fauna usually showing a change from cold to temperate climate. Many species also indicate a more southward distribution during early postglacial time. It is of importance that the marl deposits of the state

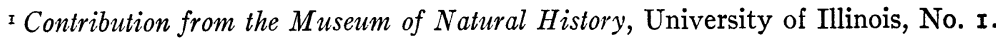


of Illinois, of which there are doubtless many, should be examined carefully and their biota compared with the recent biota of the same region and with localities within the range of the different species. This is especially true as regards deposits of an interglacial character.

Three new marl deposits are discussed in the present paper, two near Mahomet, on the Sangamon River, and the third on the campus of the University of Illinois, in Urbana.

\section{THE URBANA DEPOSITS}

Excavations for the new greenhouse and for drains in the neighborhood show the following superposition of strata (section made by Dr. T. E. Savage):

Section of ditch through old pond

4. Top soil or black clay without pebbles, grading down into number 3 below.............20-24 inches

3. Clay, dark above, becoming light gray and more calcareous below; containing numerous mollusks...................... I $8-20$ inches

2. Marl or limestone composed of more or less completely broken shells somewhat consolidated by cement of $\mathrm{CaCo}_{3} \ldots \ldots \ldots \ldots \ldots \ldots \ldots \ldots$ 8-12 inches

r. Glacial till, pebbly, gray............ 6-1 2 inches

The depth of the section was about four feet.

The locality from which these fossils came is in a depression northeast of the new greenhouses, near the forest nursery. The topography at this place suggests a pond of considerable size and the molluscan life indicates quite a depth of water, at least in the center of the lake or pond. The glacial till here is the Champaign till sheet, and the body of water evidently stood in a kettle hole on the northern side of the Champaign moraine, which extends northwest and southeast through Champaign and Urbana (Leverett, I899, pl. vi). This till sheet is of early Wisconsin age, and the relation of the marl to the till suggests that the pond or lake may have been inhabited by the mollusks when the late Wisconsin ice was resting at the Valparaiso moraine. The cemented character of the marl numbered 2 in the section also suggests considerable age. This lake or pond may have drained northeastward through the present Salt Fork Valley. 
The fauna from these marls also indicates a cooler climate when the pond was occupied by the living mollusks, the southern limit of distribution of several of the species now being at a considerable distance north of this locality. Other extinct forms in this deposit were previously known only from the marls of Maine and Michigan. The distribution and other relations of the species from the Urbana deposits are shown in Table $\mathrm{I} ; x$ indicates that no authentic Illinois records are known.

TABLE I

Molluscan Distribution

\begin{tabular}{|c|c|c|c|c|c|}
\hline Molluscan Species & $\begin{array}{c}\text { Now Living } \\
\text { in Urbana or } \\
\text { Vicinity }\end{array}$ & $\begin{array}{l}\text { Nearest } \\
\text { Illinois } \\
\text { Locality }\end{array}$ & $\begin{array}{l}\text { Distance } \\
\text { from Urbana } \\
\text { in Miles }\end{array}$ & $\begin{array}{c}\text { Fossil } \\
\text { Only }\end{array}$ & $\begin{array}{l}\text { Known from } \\
\text { Marl of } \\
\text { Michigan }\end{array}$ \\
\hline 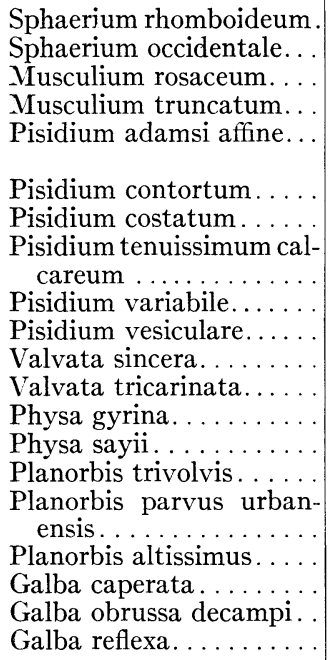 & 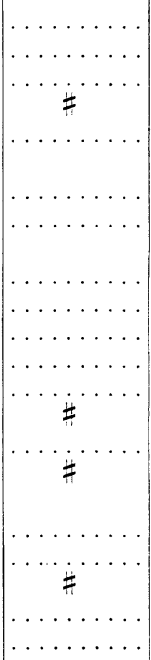 & 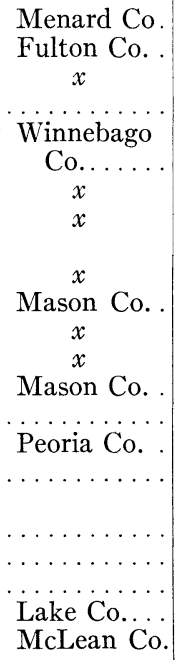 & 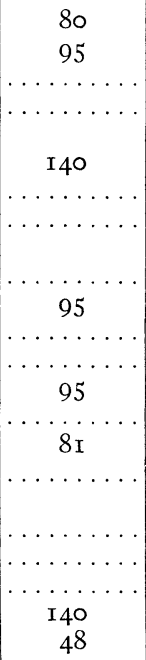 & $\begin{array}{c}{ }^{*} \\
\ldots \ldots \\
\ldots \ldots\end{array}$ & $\begin{array}{l}* \\
* \\
* \\
* \\
* \\
* \\
* \\
* \\
* \\
*\end{array}$ \\
\hline
\end{tabular}

An analysis of this table brings out several interesting features, as noted below:

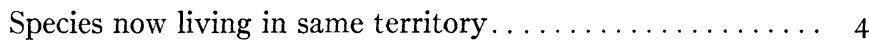

Species now living in same latitude............. Io

Species not now living in state (not yet reported) ....... 8

Extinct species...................... 4

Percentage of species also known from marl beds of

Michigan ........................ 75 per cent

Percentage of marl fauna now living in Illinois.... 70 per cent

Percentage of marl fauna now living in vicinity of

Urbana ...................... 20 per cent 
It would be of great interest to compare other marl faunas of Illinois with the one herein described. It is quite probable that the new species, as well as the species now showing a more southward distribution in Pleistocene time, will also occur in other marl deposits of the state.

The collections are in the Museum of Natural History of the University of Illinois, and are included in numbers $Z_{10755}$ to $\mathrm{Z}_{\mathrm{IO}}$ 803, inclusive.

\section{ANNOTATED LIST OF SPECIES}

\section{SPHAERIIDAE}

Sphaerium rhomboideum Prime

A portion of one right valve was the only evidence of the presence of this finger-nail clam, which is common, living in the northern part of the state.

Sphaerium occidentale Prime

One valve, apparently of this species, was observed by Dr. Sterki with a lot of Pisidia. It is a common species of the swales and small ponds in the northern half of the state.

Musculium truncatum (Linsley)

Rather plentiful. A number of specimens differ from the typical form in being larger, with narrower, more elevated beaks, which are inclined forward. Truncatum is a common species in the northern part of Illinois. The beaks of all these Musculia are strongly calyculate.

Musculium cf rosaceum (Prime)

A single valve is referred doubtfully to this species by Dr. Sterki. A single record of this species from the state is given by Wolf (1870, p. 27) for Fulton County, but the identification is doubtful. There is no authentic record from Illinois as far as known to me.

\section{Pisidium tenuissimum calcareum Sterki}

This fossil Pisidium is the most abundant mollusk in the marl bed under discussion, showing considerable variation. It has been previously known from the marls of Maine and Michigan, and its presence so far south of its hitherto recorded distribution is of great interest and indicates clearly a colder climate in early post-glacial time. 


\section{Pisidium costatum Sterki}

Next to Pisidium tenuissimum calcareum this species is the most abundant mollusk in the collection. Of this species Dr. Sterki says, "For years I thought it might be a form of Pisidium medianum, but rather different; this find appears rather to vindicate it." It has not been observed among recent Pisidia and was previously known only from marl deposits in Michigan and Maine. With the previous species this southward distribution indicates a climatic change.

\section{Pisidium vesiculare Sterki}

A few rather small but characteristic specimens occur in the collection. This species is not known from Illinois as a living mollusk. It has been observed in the marls of Michigan.

\section{Pisidium variabile Prime}

One valve of this abundant species was found in the collection. It is a common species in the northern part of Illinois, both fossil and living, and it is strange that only a trace of its presence has been left in the bed at Urbana.

\section{Pisidium adamsi affine Sterki}

A single valve of a juvenile individual occurred with other Pisidia. It is known only from Winnebago County (collected by A. A. Hinkley).

\section{VALVATIDAE}

\section{Valvata tricarinata (Say)}

Not common. The individuals are sharply tricarinate, though the majority are immature. This species is a common mollusk in the ponds, lakes, and streams of the northern part of the state. Valvata sincera (Say)

This valvata is quite common in the deposit. These are the first authentic specimens of sincera from an Illinois locality, specimens hitherto identified as sincera proving, upon examination, to be lewisii (see Baker, I806, p. 9I). The Urbana specimens of sincera were referred to Dr. Bryant Walker, who declared them to be quite typical of the species. This record indicates a wider southward distribution in early post-glacial time. 


\section{Physidae}

Physa sayii Tappan?

A single immature shell is referred doubtfully to this species. It has the characteristic shape of a half-grown sayii and is covered with heavy impressed spiral lines. The individual has $4 \frac{1}{2}$ whorls and is $12 \mathrm{~mm}$. long. Sayii is a common species in northern Illinois and the states to the north.

Physa gyrina Say

The shells of this protean species occur in abundance in the marl deposit; the greater number of individuals, however, are immature, only about 3 per cent being fully mature. The largest specimen has 6 whorls and measures $26 \mathrm{~mm}$. in length. Gyrina is distributed quite generally over the state and in the states north of Illinois.

\section{Planorbidae}

\section{Planorbis trivolvis Say}

Not common in the marl deposit and the majority of individuals are immature. Trivolvis is a very common species in Illinois and adjacent states.

Planorbis parvus urbanensis Baker, $\mathrm{n}$. var. ${ }^{\mathrm{I}}$

This new form of Planorbis parvus occurred sparingly in the marl deposits and was apparently not as abundant in the postglacial pond as the typical parous usually is in ponds of a similar character. Typical parvus occurs living in the vicinity of Urbana. Planorbis altissimus Baker, n. sp. ${ }^{\mathrm{I}}$

This new species of Planorbis is represented by a few adult individuals and a number of young and immature specimens. It was apparently not as common as the variety of parvus listed above.

\section{Galba reflexa (Say)}

\section{LYMNAEIDAE}

This Lymnaeid occurs plentifully in the marl deposit and is very abundant and variable; the majority of individuals, however, are young or immature. Reflexa is commonly distributed over the greater part of Illinois.

${ }^{\text {r }}$ The new Planorbes will be described in the current number of the Nautilus. 
Galba caperata (Say)

Caperata is abundantly distributed over the northern half of Illinois. The marl specimens are numerous, quite typical, and mostly mature.

Galba obrussa decampi (Streng)

This characteristic marl fossil is common in the Urbana marl deposit. The specimens show some peculiarities of interest. The whorls are very heavily shouldered, the sutures almost channeled, and the aperture is separated from the body whorl by a deep channel, causing the inner and outer lips to become continuous and the aperture to become auriform. There is some variation in the height of the spire and in the relative width of the shell. The collection contains both adult and young shells.

The Urbana shells give the most southern record for the distribution of the species; the only recent records from the state are in Lake and McHenry counties, and the only fossil record from post-glacial deposits is near Chicago. It is known living from a number of localities in Michigan, and from Maine, New York, and Michigan in marl beds (Baker, I9II, pp. 290-9I, pl. 32, figs. I 5-22). It is apparently a Pleistocene species that is dying out, being characteristic of the cold climate immediately following the retreat of the ice.

\section{SANGAMON RIVER, NEAR MAHOMET}

The mollusks from this locality occur in a sand stratum four feet below the surface. The fauna is distinctively of a fluviatile character and not of pond character, as is the case with the Urbana marl fauna. The species obtained by Dr. Savage are listed below:

\section{UNIONIDAE}

Fragments of a river mussel.

\section{SPHAERIIDAE}

Sphaerium solidulum (Prime)

Apparently rare. Found throughout the state.

Pisidium compressum Prime

A half-valve of this common Illinois species was found. It evidently drifted from a more favorable habitat. 


\section{VIVIPARIDAE}

Ambloxis integra (DeKay)

A post-embryonic individual and two half-grown individuals occurred in the collection. It is a common Campelona (=Ambloxis) in Illinois.

\section{VALVATIDAE}

Valvata tricarinata (Say)

Apparently a rare species in this deposit.

\section{AMNICOLIDAE}

Amnicola limosa porata (Say)

One broken shell of this common Amnicola was noted in the collection.

\section{PleUroceridae}

\section{Pleurocera elevatum (Say)}

This common river snail is very abundant in these deposits and includes the typical form together with individuals showing spiral lines on the base of the shell, indicating a tendency to vary toward the race known as lewisii. In some individuals the growth lines near the aperture are raised to form costae. All ages are represented, and the young are strongly carinate. Elevatum is distributed throughout the state.

\section{Planorbidae}

Planorbis antrosus Conrad (=bicarinatus Say)

Three specimens of this widely distributed species were observed in the collection. The single adult individual is small for the species.

\section{ENDODONTIDAE}

Pyramidula solitaria (Say)

A single broken shell of this species of land snail was found with the fresh-water species, evidently a stray individual which had fallen or been washed into the stream. 
SANGAMON RIVER, BELOW MAHOMET

About three-quarters of a mile below Mahomet, on the north bank of the Sangamon River at the first bend below the second bridge, a sand stratum occurs in a section of the river bank on the old flood plain. The stratum is about 2 inches in thickness and lies from 8 to 12 inches below the surface of the river terrace and about 5 feet above the level of the river, the latter being rather high for the season (July). The deposit can be traced for over a hundred feet in the bank. Its extent in the terrace could not be ascertained, but it is apparently considerable. At one place it disappeared beneath a large tree stump over two feet in diameter, indicating that the deposit antedated the present forest. The terrace here appears to be above the influence of the highest water, and it is evident that the deposit is post-glacial and was laid down before the Sangamon had cut its bed to the present depth. It possibly represents the flood plain of an earlier Sangamon.

It will be noted that this deposit is at a higher level than the one examined by Dr. Savage, and is probably younger. Of the species obtained from the higher level, 8 are different from those collected by Savage, and 4 species are included in the Savage collection that are not in the Baker collection. Pleurocera elevatum occurs in both collections and is still living in the Sangamon River. In both fossil deposits it is very variable in the degree of spiral ornamentation, varying, perhaps, more than the recent shells of the Sangamon. Ambloxis integrum is fairly common at the higher level deposit but rarer at the level from which Dr. Savage collected his specimens. This species lives in the Sangamon in large numbers but has not as long a spire as the fossil individuals.

The surface of the flood plain of the Sangamon River near the first bridge below Mahomet is covered with dead, bleached shells of mollusks, of the same species, mostly, as those found in the deposit examined lower down the river, but they are mixed more or less with recent shells from the river and their age and stratigraphic relation cannot be definitely determined. No deposit comparable to that found in the bend of the river below Mahomet was observed here, though the river bank was carefully examined for a 
considerable distance. It is not safe to list such material, and it has therefore been ignored.

The list of mollusks obtained from the high-level deposit is as follows:

\section{SPHAERIIDAE}

Sphaerium sulcatum (Lamarck)

Rare, only a half-valve was found.

Sphaerium stamineum (Conrad)

Not abundant, 7 valves included in the collection. Sphaerium solidulum (Prime)

A half-valve is doubtfully referred to this species by Dr. Sterki. It is broken, but is apparently the same as the shells from the lower deposit referred to this species by Sterki.

Pisidium virginicum (Gmelin)

A half-valve of this large Pisidium was found. It is common as a Pleistocene fossil and as a recent mollusk in Illinois.

Pisidium compressum illinoisense Sterki

Three valves. The presence of this recently described Pisidium in this Pleistocene deposit is of interest. It lives in a reservoir and pond in Washington County, near Dubois, and in Sheller Lake, Jefferson County, in great numbers, obtained by the veteran Illinois collector, Mr. A. A. Hinkley. Of the species Sterki says (19ı6, p. 448), "All are of the same shape, differing somewhat in size and color, but remarkably uniform in each habitat. It is a peculiar form, having almost the significance of a species." Typical compressum was the only form of this genus found in the material collected by Dr. Savage.

\section{VIVIPARIDAE}

Ambloxis integra (DeKay) ${ }^{\mathrm{r}}$

This large snail occurs in the deposit in considerable numbers; the majority of the individuals, however, are young or half-grown. The adult shells are unlike any figured in the monographs, resembling most nearly Haldeman's figure 2 of his monograph, but with

${ }^{x}$ See Pilsbry, Nautilus, XXX, pp. I09-14, I9I7, for the reasons for the change of generic name from Campeloma. 
a longer spire and deeper sutures. There are seven full whorls in the largest fossil specimen, which measures as follows: Length, 40; breadth, 22; aperture length, 20; breadth, I $2 \mathrm{~mm}$.

Integra is widely distributed in Illinois but has been confounded with subsolida and decisa, from both of which it differs notably.

\section{VALVATIDAE}

Valvata bicarinata Lea

Not common.

\section{Amnicolidae}

Amnicola limosa (Say)

Two shells of this species were observed in the loose sand taken from the aperture of Ambloxis.

\section{Pleuroceridae}

Pleurocera elevatum (Say)

As in the deposit examined by Dr. Savage, this species is the dominant mollusk in the deposits examined by the writer, and the shells exhibit the same range of variation as do those from the lower stratum. Several individuals are smooth without indication of spiral liration and every degree of ornamentation is represented to shells with a heavy, keel-like carina on the periphery. This species is abundant, living in the Sangamon River, where it is equally variable.

\section{Planorbidae}

\section{Planorbis antrosus Conrad}

Rather common, but the individuals are smaller than normal. Planorbis campanulatus Say

One adult shell of this species was found in the collection.

\section{ENDODONTIDAE}

\section{Pyramidula alternata (Say)}

Several shells of this common land mollusk were collected from the deposit, indicating that this wood snail has lived in this vicinity for a long time. It was not found in the lower deposit but a related species, Pyramidula solitaria, occurred. 
TABLE II

Relation of Molluscan Species to the Two Deposits on the SANGAMON River

\begin{tabular}{|c|c|c|c|}
\hline & Savage & Baker & $\begin{array}{l}\text { Now Living } \\
\text { in River* }\end{array}$ \\
\hline Sphaerium sulcatum............... & $\ldots \ldots \ldots$ & $x$ & $\ldots \ldots \ldots$ \\
\hline Sphaerium striatinum $\ldots \ldots \ldots \ldots \ldots \ldots$ & $\ldots \ldots \ldots$ & $x$ & $\ldots \ldots \ldots$ \\
\hline Sphaerium solidulum $\ldots \ldots \ldots \ldots \ldots \ldots \ldots$ & $x$ & $x$ & $\ldots \ldots \ldots$ \\
\hline Pisidium virginicum $\ldots \ldots \ldots \ldots \ldots \ldots \ldots$ & $\ldots \ldots$ & $x$ & \\
\hline Pisidium compressum $\ldots \ldots \ldots \ldots \ldots \ldots \ldots$ & $x$ & & $\ldots$ \\
\hline Pisidium compressum illinoisense . . . . . . . . . & & $x$ & . \\
\hline Ambloxis integra. $\ldots \ldots \ldots \ldots \ldots \ldots \ldots$ & $x$ & $x$ & $x$ \\
\hline 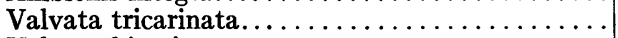 & $x$ & $\cdots$ & $\ldots \ldots \ldots$ \\
\hline Valvata bicarinata $\ldots \ldots \ldots \ldots \ldots \ldots \ldots \ldots \ldots \ldots$ & . & $x$ & $\ldots \ldots \ldots$ \\
\hline Amnicola limosa $\ldots \ldots \ldots \ldots \ldots \ldots \ldots \ldots \ldots$ & $\ldots \ldots \ldots$ & $x$ & \\
\hline Amnicola limosa porata. . & $x$ & $\ldots$ & $\ldots \ldots \ldots$ \\
\hline Pleurocera elevatum............... & $x$ & $x$ & $x$ \\
\hline Planorbis antrosus . . . . . . . . . . . & $x$ & $x$ & $\ldots \ldots \ldots$ \\
\hline Planorbis campanulatus. . . . . & & $x$ & $\ldots: \ldots$ \\
\hline Pyramidula alternata.... & & $x$ & $x$ \\
\hline Pyramidula solitaria.... & $x$ & & $\ldots \ldots$ \\
\hline
\end{tabular}

* Some of these species may be found living in the Sangamon or its vicinity.

\section{LIST OF WORKS CONSULTED}

\section{Baker, Frank Collins}

I906. "A Catalogue of the Mollusca of Illinois," Bull. Ill. State Lab. Nat. Hist., VII, art. vi, pp. 53-1 36 .

I9I I. "Post-glacial Life of Wilmette Bay, Glacial Lake Chicago," Trans. Ill. Acad. Sci., IV, ro8-I6.

I9I Ia. "The Lymnaeidae of North and Middle America, Recent and Fossil," Special Pub. III, Chicago Acad. Sci.,.I-XVI, I-539.

I9I3. "Notes on Post-glacial Mollusca, II, Waukesha County, Wisconsin," Nautilus, XXVII, 68.

I9I6. "Further Notes on the Post-glacial Biota of Glacial Lake Chicago," Trans. Ill. Acad. Sci., VII, 74-78.

BINNEy, W. G.

I865. "Land and Fresh-water Shells of North America. Part III," Smith. Miscel. Coll., No. I44, 48-49.

Haldeman, S. S.

I840. A Monograph of the Freshwater Univalve Mollusca of the United States, Including Notices of Species in Other Parts of North America, No. I, I-I6.

LeVerett, Frank

I899. "The Illinois Glacial Lobe," Mon. U.S.G. Surv. XXXVIII. 
Pilsgry, Henry A.

I9I7. "Rafinesque's Genera of Freshwater Snails," Nautilus, XXX, IO9-I4.

STERKI, VICTOR

I916. "A Preliminary Catalog of the North American Sphaeriidae," Ann. Carnegie Museum, X, 429-74.

WoLF, JoHN

I870. "Catalogue of the Shell-bearing Mollusca of Fulton County, Illinois," Amer. Jour. Conch., VI, 27. 